\title{
Hyas spp. crabs and sea anemones-new species associations from Svalbard
}

\author{
Piotr Balazy • Piotr Kuklinski • Nadya Sanamyan
}

Received: 24 July 2013 /Revised: 20 January 2014 / Accepted: 20 January 2014 / Published online: 7 February 2014

(C) The Author(s) 2014. This article is published with open access at Springerlink.com

In the literature, there is a large amount of evidence on mutual and commensal associations between actiniarians and decapods (see Ross 1983 and references therein). Among all these studies, only Davenport (1962) and Schrieken (1965) dealt with Hyas spp. Their work, however, was performed in aquaria and concerned only young crab individuals (Davenport 1962) and a single sea anemone species-Tealia felina (Linnaeus, 1767) (= Urticina felina) (Davenport 1962; Schrieken 1965). Here, we describe the association of mature H. araneus (Linnaeus, 1758) and H. coarctatus Leach, 1816 with Cribrinopsis similis Carlgren, 1921, Hormathia nodosa (Fabricius, 1780) and Urticina crassicornis (O.F. Mueller, 1776), which to our knowledge are reported for the first time. The associations were recorded during the summers of 2011 and 2012 on the rocky bottom of an Arctic fjord-Isfjord (Spitsbergen Island, Svalbard Archipelago) at 10-15 m depth.
Direct underwater observations (Fig. 1a-h) indicate that the crabs were in contact with sea anemones for several minutes. When approached by a diver, the crabs did not escape from the anemone but got closer to it. On one specific occasion, removing the rock, marked in Fig. $1 \mathrm{~g}$ with an arrow, revealed a large $(\sim 5 \mathrm{~cm}$ diameter of the pedal disc) specimen of $C$. similis attached to the crab by its verrucae (Fig. 1h).

Although sufficiently large sea anemones such as Urticina sp. have occasionally been noted in the past to feed on these crabs in this area (Gulliksen and Svensen 2004), it seems instead that the crabs, while avoiding contact with the tentacles, are searching for protection from predators (e.g. bottom-dwelling fish, octopus) as previously reported for other decapods, including those closely related to Hyas spp. (Ross 1983). More studies are needed to verify and confirm whether these associations have just a short-term facultative commensalistic character.

P. Balazy $(\bowtie) \cdot$ P. Kuklinski

Marine Ecology Department, Institute of Oceanology, Polish

Academy of Sciences, Powstancow Warszawy 55,

Sopot 81-712, Poland

e-mail: balazy@iopan.gda.pl

N. Sanamyan

Kamchatka Branch of Pacific Geographical Institute, Far-Eastern Branch of the Russian Academy of Sciences,

Partizanskaya Str. 6, Petropavlovsk-Kamchatsky 683000, Russia 
Fig. 1 A subset of pictures showing Hyas coarctatus $(\mathbf{a}, \mathbf{b}, \mathbf{e}, \mathbf{f}), H$. araneus $(\mathbf{c}, \mathbf{d}, \mathbf{h})$ and Hormathia nodosa (a), Uriticina crassicornis $(\mathbf{b}, \mathbf{c}, \mathbf{d})$, and Cribrinopsis similis $(\mathbf{e}, \mathbf{f})$ before removing the stone (g) and after (h)
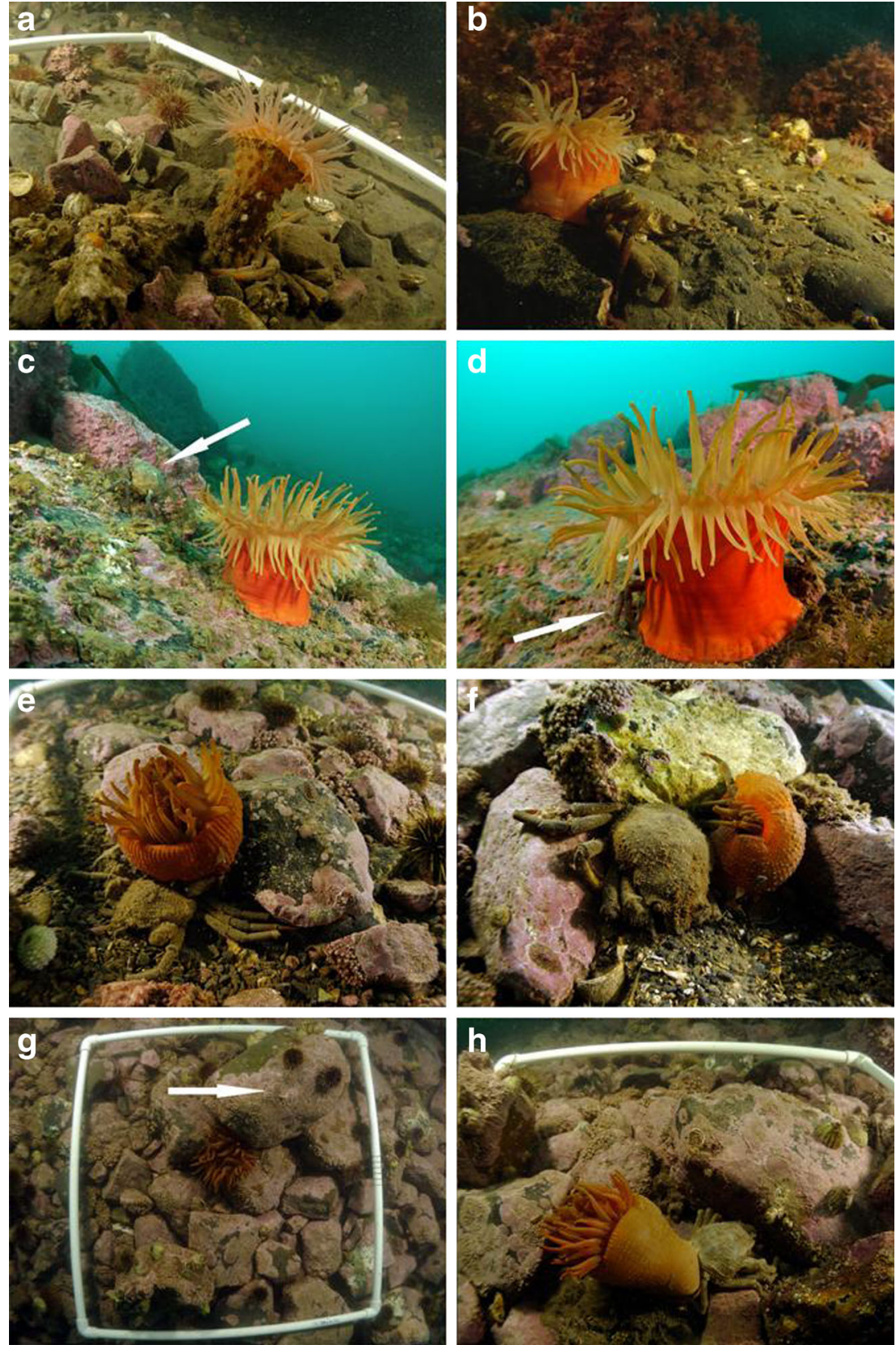

Acknowledgments Agnieszka Kostrzynska and Michal Saniewski for underwater assistance, Tomasz Borszcz for surface support and Joanna Legezynska for valuable discussion. The study has been completed thanks to grant (DEC-2011/01/N/NZ8/04493) from the National Science Centre which provided financial support to PB.

Open Access This article is distributed under the terms of the Creative Commons Attribution License which permits any use, distribution, and reproduction in any medium, provided the original author(s) and the source are credited.

\section{References}

Davenport D (1962) Physiological notes on actinians and their associated commensals. Bull Inst Ocenaogr Monaco 1237:1-15

Gulliksen B, Svensen E (2004) Svalbard and life in polar oceans. Kom, Kristiansund

Ross DM (1983) Symbiotic relations. In: Abele LG (ed) The biology of Crustacea, Vol. 7. Academic, New York, pp 163-212

Schrieken B (1965) Spinkrabben en zeeanemonenen. Levende Natuur 58 276-279 